\title{
Candida fusiformata sp.nov., a New Yeast from Cabbages and Cauliflowers
}

\author{
By R. W. M. BUHAGIAR \\ Agricultural Research Council Food Research Institute, Colney Lane, \\ Norwich NR4 $7 U A$
}

(Received 6 June 1978; revised 11 August 1978)

\begin{abstract}
A new species of yeast, Candida fusiformata, is described. The strains isolated from cabbages and cauliflowers differ from all other known species of Candida on the basis of the conventional substrate utilization tests. In addition, the strains form curved or spiral-shaped mycelium and branching chains of oval to fusiform cells on which buds are often formed from acicular or ampulliform spicules.
\end{abstract}

\section{INTRODUCTION}

Forty-seven strains of a hitherto undescribed yeast species were obtained from cabbages (Brassica oleracea var. capitata cultivars Jupiter, Decema and Stark Winter), together with five strains from cauliflowers (Brassica oleracea var. botrytis cultivars South Pacific and Barrier Reef). Isolations from cabbages were carried out between 1973 and 1976 from crops harvested in Lincolnshire (Geeson, 1978) and those from cauliflowers were obtained in 1974 and 1975 from crops harvested in Warwickshire. All the strains were isolated from surface colonies on Difco Bacto YM agar at pH 3.4. In this paper, the new yeast is described, the name Candida fusiformata is proposed and the new species is differentiated from Candida edax van der Walt \& Nel and Candida humicola (Daszewska) Diddens \& Lodder which both form similar mycelial structures.

\section{METHODS}

Isolation of strains. The strains from cabbages were isolated on plates containing Difco Bacto YM agar at pH 3.4 from suspensions made by macerating ten $19 \mathrm{~mm}$ diameter discs cut from the outer wrapper cabbage leaves in $10 \mathrm{ml}$ of unadjusted sterile distilled water containing $0 \cdot 1 \%(\mathrm{v} / \mathrm{v})$ Tween 80 . The strains from cauliflowers were isolated on plates containing Difco Bacto YM agar at $\mathrm{pH} 3.4$ from suspensions made by macerating $5 \mathrm{~g}$ cauliflower florets in $20 \mathrm{ml}$ of sterile distilled water containing $0.1 \%$ (w/v) Difco Bacto peptone and $0.5 \%(\mathrm{w} / \mathrm{v}) \mathrm{NaCl}$ and adjusted to $\mathrm{pH} \mathrm{7.0.} \mathrm{Both} \mathrm{samples} \mathrm{were} \mathrm{macerated} \mathrm{in} \mathrm{a} \mathrm{Colworth}$ Stomacher (A. J. Seward, London), the cabbage discs for $90 \mathrm{~s}$ and the cauliflower florets for $2 \mathrm{~min}$. A series of 1 in 10 dilutions was made of the macerates using the respective diluents and $0.1 \mathrm{ml}$ from each dilution was spread on to the agar plates. Plates were incubated for 4 to $5 \mathrm{~d}$ at $20^{\circ} \mathrm{C}$.

Cultural and morphological tests. The cultural characteristics of the strains were studied on malt agar (van der Walt, 1970) and on YM agar (Difco Bacto). Cultures were examined after $3 \mathrm{~d}$ at $25^{\circ} \mathrm{C}$ and after 1 month at 15 or $25^{\circ} \mathrm{C}$. The morphological characteristics of the cells were studied during exponential growth at $20^{\circ} \mathrm{C}$ in shaken defined liquid medium (Barnett \& Ingram, 1955) containing D-glucose as the sole carbon source. Further morphological studies were made on cultures in $2 \%$ glucose/yeast extract/peptone-water (Difco Bacto) and malt extract broth (van der Walt, 1970) incubated for $3 \mathrm{~d}$ at $25^{\circ} \mathrm{C}$, and on potato dextrose agar (Difco Bacto) incubated for $6 \mathrm{~d}$ at $20^{\circ} \mathrm{C}$. The malt extract broth and the malt agar were both made from unhopped malt extract obtained from a local brewery.

Filamentous growth was examined on slide cultures (van der Walt, 1970) made with potato dextrose agar and with corn meal agar (both Difco Bacto).

The media used to test for ascospore formation were those described by van der Walt (1970). The strains 
were grown individually and collectively on $\mathrm{YM}$ agar and then streaked on to carrot plugs, potato plugs, malt extract agar (Difco Bacto), McClary's acetate agar, Gorodkowa agar (modified), potato dextrose agar (Difco Bacto) and V8 vegetable juice agar. The plates were incubated at $25^{\circ} \mathrm{C}$ and the search for ascospores was carried out periodically for up to 6 weeks.

The method for detecting ballistospore formation was that described by do Carmo Sousa \& Phaff (1962). Inoculated potato dextrose plates and corn meal plates (both Difco Bacto) were inverted over similar agar plates containing sterile glass slides and incubated at 20 or $5{ }^{\circ} \mathrm{C}$. The bottom plates were examined for growth and the glass slides were searched microscopically for ballistospores for up to $18 \mathrm{~d}$.

Physiological tests. The aerobic substrate utilization tests were carried out by the method of Buhagiar \& Barnett (1971) on liquid defined medium (Barnett \& Ingram, 1955) but the rocked tubes of liquid media were incubated at $20^{\circ} \mathrm{C}$ for $28 \mathrm{~d}$. The anaerobic fermentation test was as described by van der Walt (1970) but $0.1 \mathrm{M}$-D-glucose was used as the sole carbon source.

The strains were examined for amyloid material, pulcherrimin pigment, acid production, hydrolysis of urea, acid and arbutin splitting and the liquefaction of $12 \%$ (w/v) gelatin (Difco Bacto) by the method described by van der Walt (1970). The reaction on litmus milk (Oxoid CM45) was tested as described by Lodder \& Kreger-van Rij (1952) and the utilization of $n$-decane and $n$-hexadecane was tested by the method of Markovetz \& Kallio (1964) as modified by Buhagiar (1975).

Pectinolytic activity was tested on plates containing $20 \mathrm{ml}$ base medium at pH 7.2 (Evans Base Peptone, $5 \mathrm{~g}$; Oxoid Lab Lemco, $4 \mathrm{~g}$; calcium lactate, $5 \mathrm{~g}$; New Zealand agar, $15 \mathrm{~g}$; distilled water, $1000 \mathrm{ml}$ ) which was allowed to set and then overlaid with a solution containing $18 \mathrm{~g}$ sodium polypectate (Sunkist Growers, Ontario, Calif., U.S.A.), $0 \cdot 9 \mathrm{~g}$ EDTA and $50 \mathrm{ml}$ ethanol per $900 \mathrm{ml}$ distilled water, adjusted to $\mathrm{pH} 7 \cdot 4$. Pectinolytic activity was also tested on sodium polypectate medium adjusted to $\mathrm{pH} 4.8$. Plates were incubated for up to $7 \mathrm{~d}$ at $20^{\circ} \mathrm{C}$ and the areas around the colonies were examined for pectin breakdown.

The method of Eggins \& Pugh (1962) was used to test for cellulolytic activity but $5 \mathrm{~g}$ cellulose $1^{-1}$ (Whatman no. 1 filter paper, ball milled) was used. Inoculated plates were incubated at $25{ }^{\circ} \mathrm{C}$ and checked for up to $28 \mathrm{~d}$ for cellulolytic breakdown.

Cultures tested for DNA base composition were grown at $20^{\circ} \mathrm{C}$ in liquid defined medium (Barnett \& Ingram, 1955) with D-glucose as the sole carbon source. Growth was measured turbidimetrically and cells in the late-exponential phase of growth were harvested by centrifugation and washed twice with saline/ EDTA solution $(0 \cdot 15 \mathrm{M}-\mathrm{NaCl}$ and $0 \cdot 1 \mathrm{~m}$-EDTA, pH 8.0). Cells $(5$ to $6 \mathrm{~g})$ were disrupted by grinding in a mortar with liquid nitrogen and about $3 \mathrm{~g}$ of acid washed sand (BDH). The method of Marmur (1961) as modified by Barnes et al. (1977) was used to extract and purify the DNA except that an extra initial precipitation with 2-propanol was included followed by only two treatments with the ribonucleases. The base ratio was calculated from the thermal denaturation temperature $\left(T_{m}\right)$ as described by Barnes et al. (1977), and at least three $T_{m}$ determinations were done on each DNA sample.

The terminology used in describing the morphological characteristics of the cells is that defined by Ainsworth (1971), and the colour chart published by Rayner (1970) was used to determine colony pigmentation. Sugars and vitamins obtained from Sigma were used throughout and unless specified the other chemicals were obtained from BDH (analytical reagent grade).

\section{RESULTS}

\section{Cultural characteristics}

Macroscopical appearance. After $3 \mathrm{~d}$ at $25^{\circ} \mathrm{C}$, streak cultures on malt agar and YM agar were buff, vinaceous buff or occasionally rosy buff, raised, matt, wrinkled, folded, pasty, membranous, with raised margins and undulating to lobate borders. Occasionally cultures were flat, semi-glossy with convoluted leathery islets or smooth and powdery with mucoid patches. After 1 month at 15 or $25^{\circ} \mathrm{C}$, individual colonies were buff to rosy buff, matt, smooth, or wrinkled with raised margins and borders fringed with mycelium. After $7 \mathrm{~d}$ at $25^{\circ} \mathrm{C}$, a creeping pellicle was formed with cultures growing on glucose/yeast extract/ peptone-water medium and in liquid defined medium containing D-glucose.

Microscopical appearance. In exponential growth in liquid defined medium containing D-glucose, cells were oval, ovoid, curved, cylindrical, cymbiform or fusiform and measured 1.5 to $3.0 \mu \mathrm{m} \times 3.0$ to $11.5 \mu \mathrm{m}$ (rarely up to $20.0 \mu \mathrm{m}$ ). Commonly, one, two or, rarely, three oval to fusiform buds were formed on or adjacent to the apices. Occasionally single buds arose from short acicular to ampulliform spicules situated on the lateral surfaces of the cells. No droplet mechanism was observed with the spicules and, when the buds detached, the 



Fig. 1. Photomicrographs of $C$. fusiformata (DS 0574) showing early spicule formation (a), bud formation on ampulliform spicules $(b, c)$ and bud formation without a spicule $(d)$, all on Difco Bacto potato dextrose agar after $6 \mathrm{~d}$ at $20^{\circ} \mathrm{C}$; and a bud arising from one of four acicular spicules $(e)$ and bud formation without a spicule $(f)$ in glucose/yeast extract/peptone-water after $3 \mathrm{~d}$ at $25^{\circ} \mathrm{C}$. Bar marker represents $10 \mu \mathrm{m}$. Leitz phase contrast (Heine).

spicules remained attached to the mother cell. Sometimes cells formed short mycelial structures on one or both apices to which one or two buds were attached. The sizes and shapes of the cells on malt extract medium, and those on potato dextrose agar and on glucose/ yeast extract/peptone-water medium (Fig. 1), were similar to those formed on the D-glucose defined medium.

On slide cultures of potato dextrose agar and corn meal agar, no growth was obtained under the coverslip. Aerobically, filamentous growth consisted of undulating (Fig. 2a) and curved or spiral-shaped mycelium (Fig. $2 b$ ), which was often segmented and on which buds were rarely formed, and of pseudomycelium consisting of chains of cells which often formed buds on acicular or ampulliform spicules (Fig. $2 c$ ). These spicules lacked a droplet mechanism and arose near the apices or on the lateral surfaces of the filamentous cells; some cells contained up to four of these structures. Ramified chains were formed consisting of oval elongate or fusiform cells often bearing bunches of oval blastospores (Fig. $2 d$ ). Sometimes shorter budding chains consisting of fusiform or oval cells arose directly from mycelial strands (Fig. $2 e$ ) and, occasionally, whole sections of the ramified chain structures became detached causing individual cells to break off (Fig. $2 f$ ).

No clamp connections, teliospores or ascospores were observed with individual strains or with mixtures of strains.

With cultures on inverted plates (see Methods), occasionally a few colonies were formed on the catchment plate after $10 \mathrm{~d}$ incubation at $20^{\circ} \mathrm{C}$. However, cells caught on glass slides 

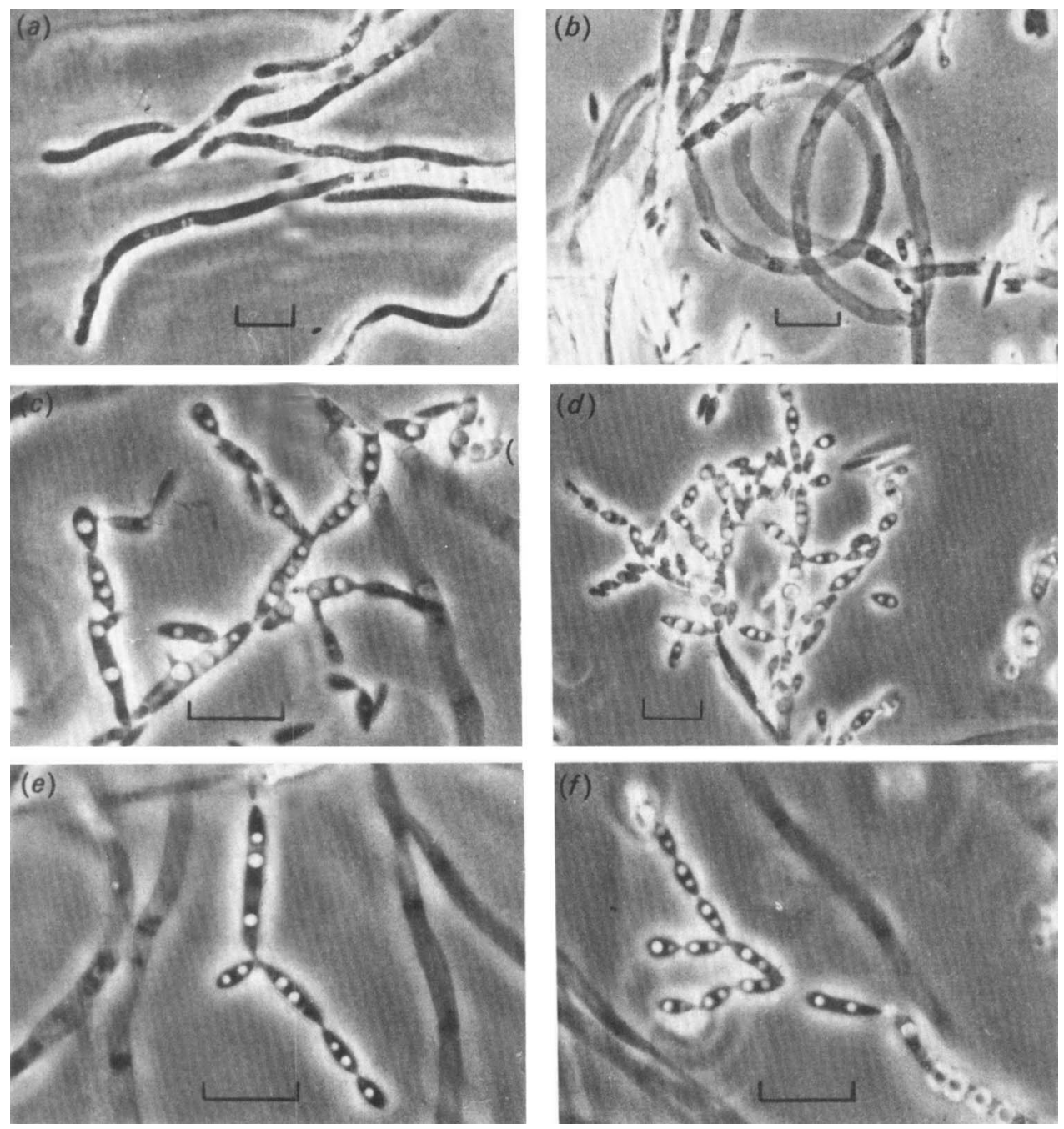

Fig. 2. Photomicrographs of $C$. fusiformata (CBs 6951) showing undulating mycelium with branching along narrow angles $(a)$, coiled segmented mycelium $(b)$, fusiform cells in chains with buds forming from lateral and near polar acicular spicules $(c)$, ramified chains of ovoid to fusiform cells $(d, e)$ and chains breaking up into individual cells $(f)$, all on Difco Bacto potato dextrose agar after $8 \mathrm{~d}$ at $25^{\circ} \mathrm{C}$. Bar markers represent $10 \mu \mathrm{m}$. Leitz phase contrast (Heine).

were not confirmed as ballistospores and, although cells on spicules were frequently formed, no droplet mechanism was observed with these structures.

\section{Physiological tests}

Anaerobic fermentation tests. In yeast water containing $0 \cdot 1 \mathrm{M}$-D-glucose none of the strains produced gas in Durham tubes.

Aerobic growth tests. Results are given in Table 1.

Other tests. On YM agar after $3 \mathrm{~d}$, growth was abundant at $30^{\circ} \mathrm{C}$ and absent at $37^{\circ} \mathrm{C}$. The strains did not grow on media with $50 \%$ (w/v) D-glucose. $n$-Decane and $n$-hexadecane were utilized as sole carbon sources although growth with $n$-decane was weak. Cells grown on $\mathrm{CaCO}_{3}$ plates produced acid; fat, arbutin and litmus milk were split; gelatin was liquefied; urea was hydrolysed; cells grown on the sodium polypectate medium at $\mathrm{pH} 7.4$ and at 
Table 1. Results of aerobic growth tests on Candida fusiformata

\begin{tabular}{lclllc}
\multicolumn{1}{c}{ Substrate } & Response & Substrate & Response & Substrate & Response \\
Raffinose & + & D-Glucose & + & Glycerol & S \\
Melezitose & + & D-Galactose & - & Erythritol & + \\
Sucrose & + & L-Sorbose & L & Ribitol & s \\
Maltose & + & L-Rhamnose & - & D-Glucitol & + \\
Trehalose & + & D-Ribose & s & D-Mannitol & + \\
Methyl $\alpha$-D-glucoside & + & D-Xylose & + & Galactitol & - \\
Cellobiose & S & D-Arabinose & + or s & myo-Inositol & + \\
Salicin & S & L-Arabinose & + & Starch & - \\
Melibiose & S or w* & Succinate & + & Inulin & s \\
Lactose & - & Citrate & + & KNO & + \\
D-Glucose without & + & Lactate & s & &
\end{tabular}

+ , Growth was more than $0.4 \mathrm{mg}$ dry wt $\mathrm{ml}^{-1}$ within $7 \mathrm{~d}$; - , no growth after 4 weeks; s, growth did not reach $0.4 \mathrm{mg}$ dry wt $\mathrm{ml}^{-1}$ until after $7 \mathrm{~d} ; \mathrm{w}$, growth reached $0.05 \mathrm{mg}^{-1}$ ry wt $\mathrm{ml}^{-1}$ within $7 \mathrm{~d}$ but not more than $0.2 \mathrm{mg}$ dry wt $\mathrm{ml}^{-1}$ within $28 \mathrm{~d}$; $\mathrm{L}$, growth only after $15 \mathrm{~d}$.

* Growth was confined to the surface.

pH 4.8 were weakly pectinolytic; cellulose was not degraded; no pulcherrimin pigment or amyloid material was formed.

The average of three DNA base ratio determinations carried out on strain DS 2974 was $58.1 \%$ GC $\left(T_{m} 93.2 \pm 0 \cdot 1^{\circ} \mathrm{C}\right)$. The standard DNA used was that of the type culture of Candida parapsilosis (CBS 604); the measured $T_{m}\left(85.8^{\circ} \mathrm{C}\right.$ ) agreed well with the stated values of $85.9{ }^{\circ} \mathrm{C}$ (Meyer et al., 1975) and $86.0 \pm 0.15^{\circ} \mathrm{C}$ (Stenderup \& Leth Bak, 1968). One strain of Candida fusiformata CBS 6951 (type strain) isolated from cauliflowers has been deposited in the collection of the Yeast Division of the Centraalbureau voor Schimmelcultures, Delft, The Netherlands.

\section{Candida fusiformata sp.nov.}

In liquore definito cum D-glucoso in augendo ad $20^{\circ} \mathrm{C}$, cellulae ovatae, ovoidae, curvatae, cylindricae, cymbiformae usque fusiformae 1.5 $\mu \mathrm{m}$ ad 3.0 $\mu \mathrm{m} \times 3.0 \mu \mathrm{m}$ ad $11.5 \mu \mathrm{m}$ (raro ad 20.0 $\mu \mathrm{m})$; singulae, binae, aut in catenis brevibus. Cellulae cum gemmis singularibus aut duobus quae in aut juxta uni apice vel ambis apicibus formatae sunt Interdum gemmae e sterigmatibus factae sunt. Cellulae cum hyphis aut pseudohyphis brevibus in uni apice vel ambis apicibus formatae sunt. In agaro farinae Zea mais et in agaro farinae Solanum tuberosum cum D-glucoso, pseudohyphae et hyphae verae formantur, sed in conditione anaerobia non sunt. Interdum, hyphae sunt in forma vel curvatae vel orbiculatae. Pseudohyphae cum cellulis fusiformis in catenis longis formantur. Ascosporae, ballistosporae non sunt. In liquore definito crescit cum raffinoso, melezitoso, sucroso, maltoso, trehaloso, methyl $\alpha$-D-glucosido, cellobioso (lente), salicino (lente), melibioso (lente, interdum exigue), D-glucoso, ,-sorboso (tarde), D-riboso (lente), $\mathrm{D}-x y l o s o, \mathrm{D}-a r a b i n o s o($ interdum lente), $\mathrm{L}$-arabinoso, succinato, citrato, lactato (lente), glycerolo (lente), erythritolo, ribitolo (lente), D-glucitolo, D-mannitolo, myo-inositolo, inulino (lente). Non crescit cum lactoso, D-galactoso, L-rhamnoso, galactitolo, amylo. Kalii nitras assimilatur. Vitaminarum addendum non necessarium est. Fermentatio nulla. In $30^{\circ} \mathrm{C}$ crescit sed non crescit in $37{ }^{\circ} \mathrm{C}$. In $50 \%$ D-glucoso non crescit. Sebum bovillum, lactem et arbutinum finduntur. Pectinum citri finditur (exigue) sed non finditur cellulosum. Gelatinum liquidum fit. Urea hydrolysatur. Acidum formatur. Materia amyloidae non formatur. Assimilantur $n$-decanum (exigue) et n-hexadecanum.Typus cultura CBS 6951 in collectione Centraalbureau voor Schimmelcultures, Delft, isolata ex Brassica oleracea var. botrytis.

\section{DISCUSSION}

Candida fusiformata strains follow the description of the genus Candida Berkhout (van Uden \& Buckley, 1970) as they are filamentous, asporogenous and do not form teliospores, 
arthrospores or ballistospores. In addition to these characteristics, C. fusiformata strains utilize myo-inositol, form cells on spicules, and produce cultures which are sometimes tinged with pink and which lack amyloid material.

The mycelial structures and physiological properties shown by $C$. fusiformata are similar to two other Candida species, C. edax van der Walt and C. humicola (Daszewska) Diddens \& Lodder. The new yeast resembles $C$. edax (CBS 5657) in that if forms curved or coiled mycelium and filamentous growth occurs only aerobically. However, unlike C. edax, C. fusiformata does not utilize lactose, D-galactose, L-rhamnose, galactitol or soluble starch as sole carbon sources; moreover, the new species is able to split fat and fails to grow at $37^{\circ} \mathrm{C}$. Candida fusiformata resembles C. humicola (CBS 571) in that it forms undulating mycelium which branches along narrow angles. However, unlike $C$. humicola, the new species utilizes $\mathrm{KNO}_{3}$ as a sole source of nitrogen, fails to utilize lactose, D-galactose, L-rhamnose and soluble starch as sole carbon sources and does not form amyloid material. The formation of fusiform cells with acicular spicules readily differentiates $C$. fusiformata from both $C$. edax and C. humicola.

Although cells from cultures of $C$. fusiformata grown on inverted plates occasionally detached themselves, these were not identified as ballistospores and cells formed on spicules lacked a droplet mechanism. Since the description of the genus Sporobolomyces states that 'the mature ballistospores are forcefully discharged into the air by a droplet mechanism' (Phaff, 1970), C. fusiformata cannot be considered ballistosporogenous.

There are other genera which form spicules from which buds are not forcefully discharged. With Aureobasidium, multiple buds arise from spicules (phialides) formed on mycelial structures (Dennis \& Buhagiar, 1973). With Sterigmatomyces, buds arise from sterigmata on vegetative cells, and with Trichosporon aculeatum, needle-shaped structures are formed on blastospores. Unlike these yeasts, the structures formed by $C$. fusiformata arise from mature fusiform-shaped cells often arranged in ramified chains. Budding on spicules is not a constant feature as in Sterigmatomyces and the species differs from Trichosporon and Aureobasidium in its mycelial characteristics and pigment formation.

Since cultures of $C$. fusiformata growing on certain media are lightly tinged with pink, the species could have been considered as Rhodotorula, but the description of this genus precludes strains which utilize myo-inositol. Similarly, the new yeast cannot be considered as a pigmented species of Cryptococcus, since the description of this genus still excludes mycelial strains, or as a species of Taphrina, the strains of which produce amyloid material and do not utilize myo-inositol or erythritol (Mix, 1954).

The specific name for Candida fusiformata (Latin fusus, spindle) refers to the spindleshaped cells commonly formed by this species.

I wish to thank Dr J. D. Geeson and Dr B. M. Lund for providing the strains, Dr D. Yarrow and Dr G. S. de Hoog of the Centraalbureau voor Schimmelcultures for advice, Mr M. J. Brown for photographic help, Mr B. J. H. Stevens for determining the DNA base composition and Mrs H. A. Belcher and Miss L. J. Nockolds for their technical assistance.

\section{REFERENCES}

Ainsworth, G. C. (1971). Ainsworth and Bisby's Dictionary of the Fungi, 6th edn. Kew: Commonwealth Mycological Institute.

Barnes, E. M., Impey, C. S., Stevens, B. J. H. \& PeEL, J. L. (1977). Streptococcus pleomorphus sp. nov.: an anaerobic Streptococcus isolated mainly from the caeca of birds. Journal of General Microbiology 102, 45-53.

Barnett, J. A. \& Ingram, M. (1955). Technique in the study of yeast assimilation reactions. Journal of Applied Bacteriology 18, 131-148.
Buhagiar, R. W. M. (1975). Torulopsis bacarum, Torulopsis pustula and Torulopsis multis-gemmis sp.nov., three new yeasts from soft fruit. Journal of General Microbiology 86, 1-11.

Buhagiar, R. W. M. \& Barnett, J. A. (1971). The yeasts of strawberries. Journal of Applied Bacteriology 34, 727-739.

do Carmo Sousa, L. \& Phaff, H. J. (1962). An improved method for the detection of spore discharge in the Sporobolomycetaceae. Journal of Bacteriology $\mathbf{8 3}, 434-435$. 
Dennis, C. \& Buhagiar, R. W. M. (1973). Comparative study of Aureobasidium pullulans, $A$. prunorum sp.nov. and Trichosporon pullulans. Transactions of the British Mycological Society $\mathbf{6 0}$, 567-575.

EgGins, H. O. W. \& Pugh, G. J. F. (1962). Isolation of cellulose-decomposing fungi from the soil. Nature, London 193, 94-95.

GeEson, J. D. (1978). The fungal and bacterial flora of stored white cabbage. Journal of Applied Bacteriology (in the Press).

LODDER, J. \& KREGER-VAN RiJ, N. J. W. (1952). The Yeasts. A Taxonomic Study. Amsterdam: North Holland Publishing Co.

Markovetz, A. J. \& Kallio, R. E. (1964). Assimilation of alkanes and alkenes by yeasts. Journal of Bacteriology 87, 968-969.

Marmur, J. (1961). A procedure for the isolation of deoxyribonucleic acid from micro-organisms. Journal of Molecular Biology 3, 208-218.

Meyer, S. A., Anoerson, K., Brown, R. E., Smith, M. Th., Yarrow, D., Mitchell, G. \& Ahearn, D. G. (1975). Physiological and DNA characterization of Candida maltosa, a hydro- carbon-utilizing yeast. Archives of Microbiology 104, 225-231.

Mix, A. J. (1954). Differentiation of species of Taphrina in culture. Utilization of carbon compounds. Mycologia 46, 721-727.

PhafF, H. J. (1970). Discussion of the yeast-like genera belonging to the Sporobolomycetaceae. In The Yeasts. A Taxonomic Study, pp. 815-862. Edited by J. Lodder. Amsterdam: NorthHolland Publishing Co.

RAYNER, R. W. (1970). A Mycological Colour Chart. Kew: Commonwealth Mycological Institute.

Stenderup, A. \& Leth BaK, A. (1968). Deoxyribonucleic acid base composition of some species within the genus Candida. Journal of General Microbiology 52, 231-236.

van Uden, N. \& Buckley, H. (1970). Candida Berkhout. In The Yeasts. A Taxonomic Study, pp. 893-1087. Edited by J. Lodder. Amsterdam: North Holland Publishing Co.

VAN DER WALT, J. P. (1970). Criteria and methods used in classification. In The Yeasts. A Taxonomic Study, pp. 34-113. Edited by J. Lodder. Amsterdam: North-Holland Publishing Co. 